\title{
Defining the Addressing Terms in Indonesian Language (A Case Study of Grorontalese)
}

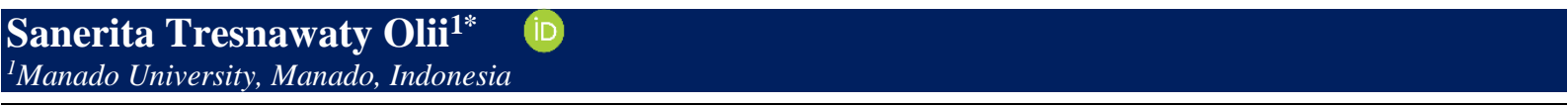

\author{
ART I CLE INFO \\ Article history: \\ Received March 22, 2021 \\ Revised March 23, 2021 \\ Accepted April 25, 2021 \\ Available online May 25, 2021

\begin{tabular}{l}
\hline Kata Kunci: \\
Istilah Sapaan, Bahasa, \\
Gorontalo \\
Keywords: \\
Addressing Terms, Language, \\
Gorontalese \\
DOI: \\
http://dx.doi.org/10.23887/jpbi.v9 \\
i1.34718
\end{tabular}

\section{A B S T R A C T}

\begin{abstract}
A B S T R A K
$\overline{\text { Sebagai salah satu aspek sosiolinguistik, istilah sapaan digunakan komunikasi sosial }}$ untuk menunjukkan hubungan dalam masyarakat dan mengacu pada nama yang mungkin berasal dari status. Indonesia memiliki banyak bahasa daerah, salah satunya bahasa Gorontalo. Di Gorontalo pada dasarnya ada banyak bahasa daerah. Tujuan penelitian ini yaitu menganalisis makna istilah sapaan yang digunakan oleh penutur bahasa Gorontalo. Metode deskriptif kualitatif digunakan dalam penelitian ini melalui wawancara. Informan diambil berdasarkan kriteria yaitu penutur asli, orang dewasa, mampu berbicara dan memahami bahasa, kemampuan berbicara yang baik, dan kelompok yang dapat diterima secara sosial. Pengumpulan data menggunakan daftar kata dan kalimat tentang istilah panggilan dalam bahasa Indonesia sebagai instrumen. Langkah menganalisis data yaitu unitisasi, kategorisasi, eksplanasi dan interpretasi. Hasil penelitian menemukan beberapa istilah sapaan dalam bahasa Gorontalo yaitu tokoh masyarakat dan agama, hubungan dengan kakek-nenek, hubungan dengan orang tua, hubungan dengan cucu, tetangga, dan teman. Istilah sapaan di sini digunakan dalam bahasa formal dan informal selama percakapan, dan setiap bahasa yang ada dalam masyarakat atau komunikasi yang berbeda memiliki karakteristik tersendiri dalam menggunakan istilah sapaan.
\end{abstract}

As one aspect of sociolinguistics, social communication is used to indicate relationships in society and refers to names that may come from status. Indonesia has many regional languages, one of which is Gorontalo. In Gorontalo, there are many regional languages. This study aims to analyze the meaning of the greeting terms used by the Gorontalo language speakers. The qualitative descriptive method was used in this study through interviews. Informants were taken based on the criteria of native speakers, adults, able to speak and understand the language, good speaking skills, and socially acceptable groups. The data collection uses a list of words and sentences about the term nicknames in Indonesian as an instrument. The steps to analyze the data are unitization, categorization, explanation, and interpretation. The study results found several greeting terms in the Gorontalo language, namely community, and religious leaders, grandparents' relationships with parents, grandchildren, neighbors, and friends. The greeting terms here are used in the formal and informal language during a conversation, and each language that exists in different or different communication has its characteristics in using the greeting term.

This is an open access article under the CC BY-SA license. Copyright (C) 2021 by Author. Published by Universitas Pendidikan Ganesha.

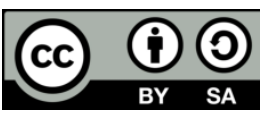

\section{INTRODUCTION}

Language is believed as the bridge that could connect humans and nations (Buran \& Filyukov, 2015; Sulistiyo, 2018). Language is a social interaction in every society, location, and period (Alias et al., 2012; Ratajczak, 2018). Social Interaction and language have a reciprocal relationship. Sociolinguistics does not focus on the structure of a language, but rather focuses on how the language is used in social life and cultural context (Eiswirth, 2020; Lomotey \& Csajbok-Twerefou, 2021). In Indonesia, many ethnic groups have their local language. These local languages serve to support the national language, which is Indonesian (Martha \& Andini, 2019; Ningrat \& Sumantri, 2019). They play a very important role in every activity of human beings. More than that, a local language is a symbol of the pride and identity of its speakers. Using two or more languages in daily communication is not a strange thing (Kurnia et al., 2015). Concerning the national language, the local language function is a device to support the development of Indonesian and national culture.

Indonesia has many local languages, one of them is Gorontalese. Gorontalese is one of the local languages which covers large areas, they are divided into several dialects such as Suwawa, Angola, and Gorontalese (Nurdin et al., 2019; Suhartono, 2015). Nevertheless, those dialects are not very different in their lexical aspects. In this research, the writer would like to focus on the Gorontalese language, especially in Diloniyohu Village. Gorontalese language is one of many local languages in Indonesia which is still used actively by most of the people in Gorontalo (Djou \& Ntelu, 2021; Hulukati et al., 2017). Gorontalese Language is used as a medium of communication among the people. The use of terms of addressing in connecting with the situation, in Gorontalese language is caused by 
two reasons: formal situation and informal situation. The formal situation shows formal speaking. In this situation, the relationship between the speakers and listeners is bound to the purposes of formality. Some examples of formal situations such as meeting, the birthday of the prophet, prayer of thanks, wedding ceremony, etc. The situation of nonformal situation speaking is often in the public places such as in the market, the place of picnic, etc. The choices of addressing terms are also influenced by the social status of a person. It refers to a hierarchy within a working group, or ranked status like teacher-pupil. In the Gorontalese system, the high or low status of someone is also distinguished by the use of addressing terms used to address him or her. In Gorontalo, there are many regional languages. However, only three languages are sufficiently known to the public in this area, namely Gorontalese, Suwawa, and Angola. In the development process, the Gorontalese language is more dominant so that it becomes more familiar to communities across Gorontalo. Currently, the Gorontalese language has been influenced by Indonesian and Manado Malay, so that the purity of the language is somewhat difficult to obtain in the narrative people of Gorontalese.

The definition of linguistics meaning is complex and thus, somewhat troublesome (Farsani et al., 2021; Su et al., 2021). Linguistics is the study of language - how it is put together and how it functions (Ren, 2021; Voorhees \& Vorobel, 2021). Various building blocks of different types and sizes are combined to make up a language. Sounds are brought together and sometimes when this happens, they change their form and do interesting things. Words are arranged in a certain order, and sometimes the beginnings and endings of the words are changed to adjust the meaning. Then the meaning itself can be affected by the arrangement of words and by the knowledge of the speaker about what the hearer will understand. Linguistics is the study of all of this. Sociolinguistic skills allow the person to deal with daily language situations (Abubakari, 2020; Wei, 2020). Sociolinguistics puts the language as part of the social system, communication system, and part of a certain community and culture. Language and society are the part that cannot be separated. The relationship between language and society has many discussions. Broadly it is discussed under the study of sociolinguistics. The term language and society have much comprehensive meaning. is the study of society and language. Sociolinguists may use surveys to examine in which contexts a language is used (e.g. market, home, school, workplace) and the attitudes to each language (particularly in multilingual contexts) (Parkvall et al., 2018; Trentman, 2017). They may look at ways that variation in a particular language correlates with social factors such as speaker age, ethnic identity, and location.

The previous researches about Gorontalese and Addressing terms have been conducted by other researchers. This study has supported the theory, in which the order and structure of Noun Phrases in both languages are distinct, while Gorontalonese is considered as a head-last language and English is a head-initial language (Muziatun, 2018). Previous research on the Influence of American Cultural Language on Thai Cultural Language (Unchit, 2016). Regarding the previous research, this research focus on addressing terms in Gorontalese particularly for those who live in Diloniyohu village. The researcher is interested to discuss and analyzed addressing terms related to Gorontalese and the questions to be answered in this study are, what are the addressing terms used by the Gorontalese speakers, and what are the meanings of those addressing terms. The purpose of this study is to analyze addressing terms related to Gorontalese and the questions to be answered in this study are, what are the addressing terms used by the Gorontalese speakers and what are the meanings of those addressing terms.

\section{METHOD}

Descriptive qualitative method is used in this research and the subject of this research is Gorontalese language, dialect spoken by those who live in Diloniyohu village where the language was actively used. The informants were taken based on the criteria proposed by reference such as native speaker, adult, being able to speak and understand the language, good speaking ability, and social acceptable group. In collecting the data, the writer used list of words and sentences concerning addressing terms in Indonesian language as the instrument. The data were collected through interview. In this case the writer interviews the chosen informants who can speak Bahasa Indonesia and Gorontalese language as well. In analyzing the data used the steps are activity of unitization, categorization, explanation and interpretation.

\section{RESULT AND DISCUSSION}

\section{Result}

The discussion of addressing terms in relation to the family consists of relation with grandparents, parents, and grand child. 
Table 1. Relation with Grandparents

\begin{tabular}{ll}
\hline Pali & Grandmother's brother \\
Mali & Grandfather's brother \\
Yali & Grandmother's sister \\
Nene & Grandmother \\
Bapu & Grandfather \\
\hline
\end{tabular}

As Shown in table 1 above, the usages of Nene, Bapu, Pali, Mali and Yali were used appropriately based on Gorontalese cultural perspective to grandparents and to older brothers and sisters' grandparents.

Table 2. Relation with Parents

\begin{tabular}{ll}
\hline Tiyamo & Father \\
Tilo & Mother \\
Kadua & Father or Mother second brother (uncle) \\
Sisa & Father's youngest sister (aunt) \\
Patua & Father's or mother's elder brother (uncle) \\
Matua & Father's or mother's elder sister (aunt) \\
Pasatu & Father's oldest brother (uncle) \\
Masatu & Pasatu's wife \\
Sadangi & Father's middle sister (aunt) \\
Aci & Father's Sister \\
Katenga & Father's or mother's middle brother (uncle) \\
Matenga & Katenga's wife \\
Pasisa & Father's youngest brother (uncle) \\
\hline
\end{tabular}

As Shown in table 2 above, the usages of Tiyamo, Tilo, Kadua, Sisa, Patua, Matua, Pasatu, Masatu, Sadangi, Aci, Katenga, Matenga and Pasisa were used appropriately based on Gorontalese cultural perspective to parents and to older brothers and sisters' parents. In English it called aunty and uncle.

Table 3. Relation with Grandchild

\begin{tabular}{ll}
\hline Kudede & Lovely brother \\
Nduna & Lovely grandson \\
Seleko & Lovely granddaughter \\
\hline
\end{tabular}

The example above explained that there are different among both relationships above. The addressing terms in relation to nonfamily relationship is the relation which there is no genetic relationship anymore but they just encountering in their intercourse environment. Whereas the addressing terms relating to family relationship, they have a genetic relationship.

Table 4. Community Leader and Religion

\begin{tabular}{ll}
\hline Podu & Neighborhood chairman \\
Ayahanda & Village chief \\
Seki & Village Secretary \\
Kepu & Headmaster \\
Sesi & Female Nurse \\
Hulango & Village midwife \\
Pulisi & Police \\
Takmirullah & Mosque Committee \\
Lebi & Leader of mosque \\
Bilale & Muezzin \\
Hatibi & Preacher at the mosque \\
\hline
\end{tabular}


Table 5. Neighbors

\begin{tabular}{ll}
\hline Nakureketo & Talkative \\
Ndule & Unknown Person \\
Kapanja & A man who has high body \\
Matinggi & Woman who has high body \\
Mada'a & Older fat woman \\
Ende & Young girl who has short body \\
Makiki & Older woman who has small body \\
Pakiki & Older man who has small body \\
Makuni & Older woman who has yellow skin \\
Palimbo & Older man whose body fat and short \\
Patinggi & Old man who has high body \\
Kahaya & Older thin and high man \\
Nahaya & Kahaya's wife \\
Pada'a & Older fat man \\
Kaputi & Older man who has white skin \\
Maputi & Older woman who has white skin \\
\hline
\end{tabular}

Table 6. Friends

\begin{tabular}{ll}
\hline Ka'ita & Man who has black skin \\
Kapende & Man who has short body \\
No'u & Young lady \\
Ambalo & Lazy man \\
Na'ita & Young Girl has blackskin \\
Mboda & Fat Wowan \\
\hline
\end{tabular}

As shown in table The discussion about addressing terms is influenced by their characteristics, for example, static is different from dynamic society. In this case the dynamic society has simple addresses, but the static society theuse of the address is tied with power system which is based on genetic. It is also more difficult compared with the dynamic society. The discussion of addressing terms which have no family relationship consist of teacher, neighbor and friends.

\section{Discussion}

The Study of personal address has always been a popular topic within sociolinguistics because address terms open communicative acts and set the tone for the interchanges that follow (McKee et al., 2021; Susanto, 2014). Addressing the term is one of the sociolinguistics aspects, it refers to a name that might come from status (Beaulieu et al., 2018; Dippold et al., 2020). Gorontalese language is one of the local languages which have a relation with the society and social aspect. As points out: It is nearly impossible to say anything without indicating the social relationship between the speaker and listener in terms of status and familiarity. Gorontalo language has three main functions. Firstly, it is a communication tool amongst its people (Baruadi, 2013). Second, it is a pillar to support and develop its own culture. The last is the identity of the people of Gorontalo. The society of Gorontalese also has rules in using the language. There are certain terms that are used in order to be culturally effective.

According to reference Addressing system is a word or phrase used to address someone (Andrade et al., 2014; Smith, 2021). The use of terms is influenced by several social factors. A variety of social factors usually govern our choice of terms, The particular occasion, The serial status or rank of the other, sex, age, family relationship, occupational hierarchy, transactional status, (i.e.a service encounter or a doctor-patient relationship or one of priest-penitent ), race or degree of intimacy (López et al., 2021; Morgan et al., 2021). The different systems of addressing may possibly allow us to gain a more objective perception of what we do with our own language and in our culture (Hofmann \& Müller, 2021; Hulukati et al., 2017). This quotation asserts that in addressing there are a number of morphemes, words or phrases used to refer to the situation, and they are different - depending on the relation between the participant of a discourse. In terms, several linguistics and factors need to be considered by the speakers. Gorontalese has its own addressing system as the other local language in our country. The terms of addressing used by Gorontalese speakers are influenced by several factors, such as situation, ethnicity, age, gender, intimateness, social status, and relationship.. 


\section{CONCLUSION}

Based on the findings above the researcher conclude that terms of addressing in Gorontalese language can be grouped into two kinds: Nonrelative Addressing Terms which have no family relationship and Relative Addressing Terms which havefamily relationship. Besides address mother, father brother and sister, Gorontalese language has uniqueness, when we address someone is based on his/her character, skin color and size of body. In Gorontalese language there are some addresses by people tohow many of them sibling. For example, Kadua: Uncle, Fatheror mother's second brother. The researcher hopes this research can be motivation for the next research as the references of the next analysis.

\section{REFERENCES}

Abubakari, H. (2020). Personal names in Kusaal: A sociolinguistic analysis. Language \& Communication, 75. https://doi.org/10.1016/j.langcom.2020.07.003

Alias, A. A., Manan, N. A. A., Yusof, J., \& Pandian, A. (2012). The use of Facebook as Language Learning Strategy (LLS) Training Tool on College Students' LLS use and Academic Writing Performance. Procedia - Social and Behavioral Sciences, 67. https://doi.org/10.1016/j.sbspro.2012.11.305

Andrade, M. S., Evans, N. W., \& Hartshorn, K. J. (2014). Linguistic support for non-native English speakers: Higher education practices in the United States. Journal of Student Affairs Research and Practice, 51(2). https://doi.org/10.1515/jsarp-2014-0020.

Baruadi, M. K. (2013). Apellation in Gorontalese: An Antropolinguistics Approach towards Language and Culture in Gorontalo Indonesia. Research on Humanities and Social Sciences, 3(16).

Beaulieu, S., Woll, N., French, L. M., \& Duchemin, M. (2018). Language learners' metasociolinguistic reflections: A window into developing sociolinguistic repertoires. System, 76. https://doi.org/10.1016/j.system.2018.07.001

Buran, A., \& Filyukov, A. (2015). Mind Mapping Technique in Language Learning. Procedia - Social and Behavioral Sciences, 206. https://doi.org/10.1016/j.sbspro.2015.10.010

Dippold, D., Lynden, J., Shrubsall, R., \& Ingram, R. (2020). A turn to language: How interactional sociolinguistics informs the redesign of prompt:response chatbot turns. Discourse, Context \& Media, 37. https://doi.org/10.1016/j.dcm.2020.100432

Djou, D. N., \& Ntelu, A. (2021). Bahasa Gorontalo dan Bahasa Suwawa pada Anak Usia Dini. Jurnal Obsesi, 5(2). https://doi.org/10.31004/obsesi.v5i2.895

Eiswirth, M. E. (2020). Increasing interactional accountability in the quantitative analysis of sociolinguistic variation. Journal of Pragmatics, 170. https://doi.org/10.1016/j.pragma.2020.08.018

Farsani, M. A., Jamali, H. R., Beikmohammadi, M., Ghorbani, B., \& Daneshvar, L. S. (2021). Methodological orientations, academic citations, and scientific collaboration in applied linguistics: What do research synthesis and bibliometrics indicate? System, 100. https://doi.org/10.1016/j.system.2021.102547

Hofmann, V., \& Müller, C. M. (2021). Language skills and social contact among students with intellectual disabilities in special needs schools. Learning, Culture and Social Interaction, 1. https://doi.org/10.1016/j.lcsi.2021.100534

Hulukati, W., Rahim, M., \& Djafar, Y. (2017). Pembelajaran Bahasa Daerah Gorontalo Pada Anak Usia Dini. VISI: Jurnal Ilmiah Pendidik Dan Tenaga Kependidikan Pendidikan Non Formal, 12(1). https://doi.org/10.21009/JIV.1201.8

Kurnia, D., Taufiq, M., \& Silawati, E. (2015). Analisis Capaian Perkembangan Bahasa Anak Usia Dini Dalam Kegiatan Pembelajaran Dengan Metode Learning Based Resources. Cakrawala Dini: Jurnal Pendidikan Anak Usia Dini, 6(2). https://doi.org/10.17509/cd.v6i2.10520

Lomotey, B. A., \& Csajbok-Twerefou, I. (2021). A pragmatic and sociolinguistic analysis of proverbs across languages and cultures. Journal of Pragmatics, 182. https://doi.org/10.1016/j.pragma.2021.06.014

López, K. M. J. de, Feilberg, J., Baena, S., Lyons, R., \& Lyons, R. (2021). "So, I told him to look for friends!" Barriers and protecting factors that may facilitate inclusion for children with Language Disorder in everyday social settings: Cross-cultural qualitative interviews with parents. Research in Developmental Disabilities, 115. https://doi.org/10.1016/j.ridd.2021.103963

Martha, nia ulfa, \& Andini, novita pri. (2019). Pengembangan Bahan Ajar Mata Pelajaran Bahasa Indonesia Berbasis Cerita Rakyat Kabupaten Banjarnegara. Jurnal Inovasi Pembelajaran, 5(2). https://doi.org/10.22219/jinop.v5i2.9992

McKee, R., Safar, J., \& Alexander, S. P. (2021). Form, frequency and sociolinguistic variation in depicting signs in New Zealand Sign Language. Language \& Communication, 79. 
https://doi.org/10.1016/j.langcom.2021.04.003

Morgan, G., Curtin, M., \& Botting, N. (2021). The interplay between early social interaction, language and executive function development in deaf and hearing infants. Infant Behavior and Development, 64. https://doi.org/10.1016/j.infbeh.2021.101591

Muziatun. (2018). Contrastive Analysis: Gorontalonese and English Noun Phrase. Journal of Arts and Humanities, 8(1). https://doi.org/10.18533/journal.v8i1.1561

Ningrat, S. P., \& Sumantri, M. (2019). Kontribusi Gaya Belajar Dan Motivasi Belajar Terhadap Hasil Belajar Bahasa Indonesia Siswa Kelas V Sd. Journal of Education Technology, 2(4), 145. https://doi.org/10.23887/jet.v2i4.16426

Nurdin, iti S. I., Katili, M. D. N. O., \& Ahmad, M. Z. F. (2019). Faktor ibu, pola asuh anak, dan MPASI terhadap kejadian stunting di kabupaten Gorontalo. Jurnal Riset Kebidanan, 3(2). https://doi.org/10.32536/jrki.v3i2.57

Parkvall, M., Bakker, P., \& McWhorter, J. H. (2018). Creoles and sociolinguistic complexity: Response to Ansaldo. Language Sciences, 66. https://doi.org/10.1016/j.langsci.2017.10.001

Ratajczak, M. (2018). Language and value: the philosophy of language in the post-Operaist critique of contemporary capitalism. Language Sciences, 17. https://doi.org/10.1016/j.langsci.2018.08.004

Ren, J. (2021). Variability and functions of lexical bundles in research articles of applied linguistics and pharmaceutical sciences. Journal of English for Academic Purposes, 50. https://doi.org/10.1016/j.jeap.2021.100968

Smith, S. A. (2021). Exploring knowledge of transparent and non-transparent multi-word phrases among L2 English learners living in an Anglophone setting. System, 101. https://doi.org/10.1016/j.system.2021.102590

Su, H., Zhang, Y., \& Lu, X. (2021). Applying local grammars to the diachronic investigation of discourse acts in academic writing: The case of exemplification in Linguistics research articles. English for Specific Purposes, 63. https://doi.org/10.1016/j.esp.2021.05.002

Suhartono. (2015). Ketimpangan Dan Pembangunan Ekonomi Kabupaten/Kota Di Daerah Hasil Pemekaran: Studi Kasus Di Provinsi Banten Dan Gorontalo. Jurnal Ekonomi Kebijakan Publik, 6(1). https://doi.org/10.22212/jekp.v6i1.154

Sulistiyo, U. (2018). Factors Affecting English Language Learning in English as a Foreign Language (EFL) Context: A Literature Review Study. Indonesian Journal Of Educational Research, 3(1), $20-24$. https://doi.org/10.30631/ijer.v3i1.54

Susanto, D. (2014). The Pragmatic Meanings of Address Terms Sampeyan and Anda. Indonesian Journal of Applied Linguistics, 4(1). https://doi.org/10.17509/ijal.v4i1.606

Trentman, E. (2017). Oral fluency, sociolinguistic competence, and language contact: Arabic learners studying abroad in Egypt. System, 69. https://doi.org/10.1016/j.system.2017.08.007

Unchit. (2016). A CDA of Thai and American Music Radio Programs in Terms of the Influence of the Language of American Culture on the Language of Thai Culture. Journal of English Language Teaching and Linguistics, 1(2). https://www.onesearch.id/Record/IOS3363.article-22? widget=1\&repository_id=3363

Voorhees, T. T., \& Vorobel, O. (2021). Integrating Qualitative Research into the Community College Linguistics Course: An Autoethnographic Inquiry. International Journal of Educational Research Open, 2. https://doi.org/10.1016/j.ijedro.2021.100053

Wei, L. (2020). The sociolinguistics of voice in globalising China. Systemic, 94. https://doi.org/10.1016/j.system.2020.102356 